DOI: https://doi.org/10.34069/AI/2021.43.07.21

How to Cite:

Novikov, S.V. (2021). Ensuring the territorial connectivity in the arctic region of the Russian Federation: urgent scientific and technical tasks. Amazonia Investiga, 10(43), 209-218. https://doi.org/10.34069/AI/2021.43.07.21

\title{
Ensuring the territorial connectivity in the arctic region of the Russian Federation: urgent scientific and technical tasks
}

\section{Обеспечение Связанности Территории в Арктической Зоне Российской Федерации: Актуальные Научно-Технические Задачи}

Written by:

Sergey V. Novikov ${ }^{78}$

https://orcid.org/0000-0001-6921-1760

https://www.scopus.com/authid/detail.uri?authorId=57192318711

https://www.elibrary.ru/author_profile.asp?id=807011

\begin{abstract}
The article proposes an approach to the definition of complex scientific and technical tasks to ensure the connectivity of the Arctic region of the Russian Federation. Having studied strategic planning documents, citizens' proposals in the formulation of the National Programme for the Development of the Far East and scientific publications, we have drawn up a list of problems with complex tasks and scientific and technical tasks. In order to effectively problems' solution of the spatial development of the Arctic regions, it is necessary to introduce new technologies that ensure the energy, transport, information and socio-cultural connectivity of sparsely populated and inaccessible areas. The article presents a list of the scientific and technical tasks required for the development of such technologies.
\end{abstract}

Keywords: arctic zone (region) of the Russian Federation; innovative vehicles; complex scientific and technical programmes and fullinnovation projects; territorial connectivity; Strategy for Scientific and Technological Development (SSTD).

\begin{abstract}
Абстрактный
В статье изложен подход к определению комплексных и научно-технических задач для обеспечения связанности территории Арктической зоны Российской Федерации. $\mathrm{Ha}$ основе изучения документов стратегического планирования, предложений, поступивших от граждан при разработке Национальной программы развития Дальнего Востока, научных публикаций, был сформирован перечень проблем, комплексных задач и научнотехнических задач в их составе. Для эффективного решения проблем пространственного развития арктических регионов необходимо внедрение новых технологий, позволяющих обеспечивать энергетическую, транспортную, информационную и социокультурную связанность малонаселенных и труднодоступных территорий. В статье представлен перечень научно-технических задач, решение которых необходимо для разработки и применения таких технологий.
\end{abstract}

\begin{tabular}{|c|c|}
\hline Ключевые & Арктическая \\
\hline $\begin{array}{l}\text { Российской } \\
\text { транспортные }\end{array}$ & $\begin{array}{c}\text { Федерации; } \\
\text { средства; }\end{array}$ \\
\hline научно-технич & кие программы и п \\
\hline территорий; & Стратегия \\
\hline
\end{tabular}

\footnotetext{
${ }^{78} \mathrm{PhD}$ in Econimic Sciences, Associate Professor, Moscow Aviation Institute (National Research University), Moscow, Russia.
} 


\section{Introduction}

The integrated development of the Arctic region of the Russian Federation is defined as a priority state task in a number of strategic planning documents at the federal level.

Decree of the President of the Russian Federation of March 5, 2020 No. 164 approved the Fundamentals of State Policy of the Russian Federation in the Arctic region for the period up to 2035. According to the Spatial Development Strategy (approved by the order of the Government of the Russian Federation of February 13, 2019 No. 207-r), the priority tasks for the development of the Arctic zone of the Russian Federation are the following:

- ensuring sustainable year-round transport connection to sparsely populated and island territories of the Arctic zone and Far East, isolated from the unified transport system of the Russian Federation;

- promoting the development of distributed generation, including on the basis of renewable energy sources, primarily in remote and hard-to-reach areas with the necessary natural conditions and resources;

- $\quad$ stimulation of the advanced development and implementation of energy-saving and energy-efficient technologies, primarily in the Arctic zone of the Russian Federation and in the Far North and equivalent areas.

In SSTD (approved by the Decree of the President of the Russian Federation No. 642 of December 1, 2016), the effective development of the Arctic is indicated as a part of the priority of scientific and technological development, defined by paragraph 20e of SSTD: Territorial connectivity of the Russian Federation through the creation of intelligent transport and telecommunication systems, as well as occupation and retention of leadership positions in the creation of international transport and logistics systems, development and use of space and air space, World Ocean, Arctic and Antarctic.

The implementation of this priority of scientific and technological development should be a response to the "big challenge", which is the "need for effective development and use of space, including by overcoming disparities in the socio-economic development of the country's territory, as well as strengthening Russia's position in the economic field, scientific and military exploration of space and air space, World Ocean, Arctic and Antarctic".

\section{Literature Review}

The determination of the priorities of the spatial development of Russia at the turn of the 20th and 21 st centuries has become the subject of a broad socio-political and scientific discussion.

The collapse of the Soviet Union, rejection of the communist ideology and socialist principles of management, planned economy, directive management of the system of settlement and distribution of productive forces led to a sharp increase in the tendency to shrink previously developed territories in the North and East of the country.

During the period from 1990 to 2018, the population living in the Arctic regions of the Russian Federation decreased by more than 1.9 million people, that is, it decreased by almost a quarter. The age structure of the population has also undergone significant changes unfavorable for the economy. In particular, there are tendencies towards a decrease in the proportion of people of working age (Voronina et al., 2018).

According to A.G. Shelomentsev, the highest migration outflow of the population from the Arctic Far Eastern regions is natural, since they are the most severe in natural and climatic terms and the most distant from the central regions of the country. Low transport accessibility and focal distribution of the population make it difficult to organize normally functioning systems of education, health care and social protection in these territories (Shelomentsev et al., 2018).

The growing negative changes in the systems of settlement and distribution of productive forces in the Russian Artik are described by A.L. Bezrukov as a turn in the opposite direction of the traditional centuries-old trends in the formation of economic and settlement structures in Siberia, which previously represented settlement and development. The researcher notes the growth of such negative trends as an increase in the differentiation of districts and points in terms of the level of socio-economic well-being, with an increase in the peripheralization and even marginalization of most of them; partial de-industrialization and primitivization of the economy; "Compression" of the developed and populated space; pulling together of the remaining population in regional centers, large cities and their agglomerations with an increase in central-peripheral polarization, degradation and depopulation of the population in the peripheral zones (Bezrukov, 2015). 


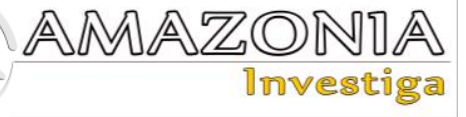

In 2003, American researchers F. Hill and G. Gaddy published the book "The Siberian Curse. How Communist Planners Left Russia Out in the Cold", in which a systematic attempt was made to identify and analyze the causes of the problems described above in the spatial development of post-Soviet Russia (Hill and Gaddy, 2003).

According to the authors of the study, today, despite the elimination of central planning, a non-market and undemocratic distribution of labor and capital remains on the territory of Russia. F. Hill and G. Gaddy believe that Russia is burdened with problems and costs associated with the size of the territory and harsh climatic conditions, more than any other large country in the northern latitudes, in particular the United States, Canada or the Scandinavian countries.

If in earlier eras the vast territory of Russia was " source of prosperity, strength and invincibility", then in modern conditions "size is more likely not an asset, but a liability, an obstacle to economic competition and effective management." As the motives that prompted the Soviet state to settle and industrialize the Siberian, including the Arctic territories, F. Hill and G. Gaddy point to the need for self-sufficiency in strategic mineral resources, the creation of a defensive center in the interior of the country, as well as the formation of the ideology of "development of new lands".

The result of this policy was the emergence on the territory of Siberia of numerous "city-plants", in modern terminology: "single-industry towns", for which a decline or complete cessation of production at a city-forming enterprise lead to a deep socio-economic crisis, since such cities "were built more for the needs of industry and the state than for the needs of the people, " F. Hill and G. Gaddy note.

American researchers have formulated for Russia the following in terms of changing priorities for spatial development: "Instead of fixing a backward economy by continuing to invest in Siberia, Russia should do the opposite. It needs to focus on the revitalization of potentially most productive regions, primarily in the European part of the country. A significant part of today's Siberian population should move to these areas, warmer and closer to European markets. "

The publication of the "Siberian Burden" (in some translations - " Siberian curse") caused a sharp controversy. In many respects agreeing with the descriptive part of the study, Russian scientists, politicians and publicists categorically object to the conclusions and recommendations for "moving the population of Siberia" to warmer regions.

So A.L. Bezrukov in the work cited above points to " intensification of pressure from the West on Russia", notes that "Siberia is undergoing the greatest attacks, whose riches are an object of inexhaustible envy for world powers." The author believes that the "inefficiency of the Siberian economy" is caused not by objective climatic and geographical factors, but by "sharp disparities between the volume of production in Siberia and the amount of income it receives," which "go beyond all reasonable limits." According to A.L. Bezrukov, in order to overcome negative trends in the socio-economic development of this macroregion, it is necessary to "consciously use the set of adaptive methods and methods of organizing economic activity, tested over decades, and establish a fair financial and economic balance of relations between the center and Siberian regions."

Detailed comments to the "Siberian Curse" by F. Hill and C. Gaddy are also presented in the article by T.M. Mikhailova (Mikhailova, 2011).

The author agrees with American researchers that "cold winters on the Russian map are synonymous with an unfortunate geographic location, especially from the standpoint of modern economics, when geographic proximity to natural resources plays an ever smaller role, and proximity to people, markets and agglomerations is increasingly important" ...

T.N. Mikhailova states: "The country is facing the problem of increasing inequality in the economic situation of the regions and, consequently, in the living standards of people", in fact repeating the formulation of the "big challenge" from the Strategy of Scientific and Technological Development of the Russian Federation in terms of "overcoming imbalances in social-economic development of the country's territory".

According to T.N. Mikhailova, massive investments in traditional modes of transport cannot become an effective tool for significantly reducing the distance to markets and ensuring the growth of regional economies in the Arctic and Siberian regions, which confirms the relevance of the task set in this article to develop innovative modes of transport and its systems that do not need its traditional infrastructure in order to 
ensure the connectivity of the territory in the Arctic zone of the Russian Federation.

\section{Theoretical Basis}

The main tool for implementing SSTD is complex scientific and technical programmes and projects of the complete innovation cycle, the result of which should be products, services and technologies that are in demand on the market, which will effectively and costeffectively solve urgent problems of the socioeconomic development of the country and regions.

The formation and selection of complex scientific and technical programmes and projects of the full innovation cycle should be provided with advice on priority areas of SSTD. Such programmes will be approved by the Government of the Russian Federation in accordance with the Rules established by the Decree of the Government of the Russian Federation of February 19, 2019 No. 162.

Currently, the Council for the Priority of Scientific and Technological Development "Territorial Connectivity of the Russian Federation" (clause 20e of SSTD) is working on the formation of complex scientific and technical programmes and projects of a full innovation cycle aimed at ensuring the territorial connectivity in the Arctic zone of the Russian Federation.

Territorial connectivity is a property of the territory that allows timely and cost-effective movement of people, goods and information (Pogosyan et al., 2019).

Territorial connectivity is a prerequisite for solving the following economic, social and management tasks:

- meeting the needs of a person, social groups, development of society (social aspect of territorial connectivity, formation of social standards and ensuring their implementation);

- meeting the needs of business entities and economic development (economic aspect of territorial connectivity);

- ensuring state and municipal needs, exercising the powers of state authorities and local self-government (political and administrative aspects of territorial connectivity, strategic planning of socioeconomic development and ensuring national security).
In SSTD, the priority of scientific and technological development, defined by paragraph 20f, is formulated as broadly as possible. In order to form complex scientific and technical programmes and projects of the full innovation cycle, which can become an effective response to the corresponding "big challenge" specified in SSTD, it is necessary to determine the urgent complex and scientific and technical problems, which should be addressed by such programmes and projects.

As G.V. Shepelev rightly noted, the work on the formation of priorities for scientific and technological development must be supplemented by the elaboration of specific socio-economic problems, for the solution of which scientific and technical research is needed: "Such approved tasks could become real priorities for the organization of scientific research, structural reforming the organizations of the public sector of science, concentration of resources on the demanded scientific and technical developments. Such work could be built, for example, on the basis of councils created for the implementation of SSTD on priority areas of scientific and technological development, involving federal and regional executive authorities in the formulation of problems that are relevant for them and in the solution of which scientific research is important component" (Shepelev, 2020).

The Council for the priority direction "Territorial Connectivity of the Russian Federation" for the purpose of scientific and technological support of the socio-economic development of the Arctic zone of the Russian Federation, the development of complex scientific and technical programmes and projects of a full innovation cycle has been formed:

- $\quad$ list of complex problems of socio-economic development of the Arctic zone of the Russian Federation;

- list of complex socio-economic tasks for the solution of which it is necessary to ensure the territorial connectivity of the Arctic zone of the Russian Federation;

- $\quad$ list of scientific and technical tasks as a part of complex socio-economic tasks in the field of the priority of scientific and technological development "Territorial connectivity of the Russian Federation".

The complex problem of the socio-economic development of the Arctic zone of the Russian Federation here is a fundamental problem that hinders the socio-economic development of the 


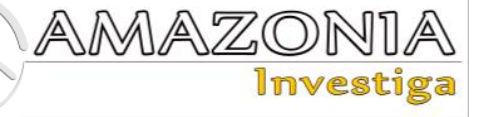

region and has a significant impact on the quality of life in the region and the efficiency of economic activity.

A complex task is a task of the socio-economic development of a region, the solution of which is necessary to overcome a complex problem.

A complex scientific and technical task as part of a complex task is a task for the solution of which a complex scientific and technical project (programme) of a complete innovation cycle is formed, the result of which should be new products (services) in demand in the economy, the use of which contributes to solving a complex problem, increases quality of life and efficiency of economic activity.

\section{Methodology}

In order to identify the most urgent and requiring urgent solutions to complex problems of socioeconomic development of the Arctic regions of the Russian Federation, the following sources were analyzed:

- $\quad$ strategic planning documents of the federal and regional levels (current and under development, including the drafts of the National Programme for the Development of the Far East, Strategy for the Development of the Arctic Zone of the Russian Federation, new edition of the socio-economic development of this geo-strategic region);

- proposals submitted to the National Programme for the Development of the Far East until 2025 from residents of the region (a total of 16518 proposals were received on the portal https://дв2025.pф/) (Дв2025.pф, 2018);

- proposals for the social section of the National Programme for the Development of the Far East until 2025, prepared by the federal autonomous scientific institution "Eastern Center for State Planning";

- materials of the $\mathrm{V}$ International Arctic Forum "Arctic is the Territory of Dialogue", which took place on April 9-10, 2019 in Saint Petersburg, including the materials of the session "Comprehensive Scientific and Technical Programmes and Projects for the Development of the Arctic: Dialogue of Potential Partners".

\section{Results}

Based on the analysis of these sources, the following problems were included in the list of complex problems of the socio-economic development of the Arctic zone of the Russian Federation, noted as the main and most urgent for government bodies, population and economic entities:

- outflow of population from the region;

- destruction of life support infrastructure (dilapidated and emergency housing, deterioration of communal infrastructure);

- low level of transport connectivity of territories;

- low availability of quality education and social and cultural services;

- insufficient economic and physical accessibility of transport and logistics services for the population and business entities (Grebennikov et al., 2012);

- insufficient physical and economic availability of quality food products;

- significant difficulties in the provision of emergency medical care;

- $\quad$ lack of jobs, high unemployment and high proportion of the population with incomes below the subsistence level;

- impossibility of promptly receiving public services by the population (obtaining documents, registering legally significant actions, etc.).

Table 1 groups complex socio-economic tasks, for the solution of which it is necessary to ensure the territorial connectivity of the Arctic zone of the Russian Federation, and for each of such task, a list of scientific and technical tasks is provided. 
Table 1.

Complex socio-economic tasks.

Complex socio-economic tasks, for the
solution of which it is necessary to
ensure the territorial connectivity of
the Arctic zone of the Russian
Federation

Increasing the physical and economic accessibility for the population and business entities of transport and logistics services, ensuring safe, timely and cost-effective delivery of goods and passengers, access to the development of natural resources.

Increasing the physical and economic accessibility for the population and business entities of energy supply services that ensure the reliability, safety and sustainability of life support systems and production facilities

Improving living conditions, quality of living environment, improving the quality of life, creating conditions for the full realization of human potential in areas with low population density

Improving the performance of vehicles and engineering and transport infrastructure

Improving the quality of planning and administration of integrated development and development of territories, ensuring the population's access to basic social and cultural benefits

\section{Scientific and technical tasks as a part of complex socio-economic tasks}

Development of innovative vehicles that do not need traditional transport infrastructure (small aircraft, airships, amphibious vehicles), unmanned aerial and ground transport and logistics systems, infrastructure elements to ensure multimodal transportation

Creation of an integrated digital platform for interaction between carriers (transport companies, private carriers and individual vehicle owners) and customers (passengers, shippers) to ensure mobility and provide transport and logistics services by all modes of transport

Development of models for managing the demand for electricity in a decentralized energy supply

Development of technically and cost-effective energy storage devices

Development of technically and economically efficient multi-fuel power plants

Development of hybrid autonomous power supply systems Development of a complex of technological solutions (life support systems, urban planning and architectural solutions) for the development of territories and existing settlements, allowing them to provide living conditions comparable to urban agglomerations

Creation of high-strength and corrosion-resistant structures and protective coatings that provide increased requirements for the performance of vehicles and engineering and transport infrastructure under extreme climatic conditions

Creation of a system of information and analytical support for making managerial decisions by state and local authorities, including decisions on the choice of priorities for socio-economic development, optimization of the model of resettlement and placement of productive forces, model of transport and logistics services and model of energy supply
The creation of an integrated digital platform for interaction between carriers (transport companies, private carriers and individual vehicle owners) and customers (passengers and shippers) to ensure mobility and provide transport and logistics services by all modes of transport will allow planning supply chains and routes of vehicles, communication with state traffic control structures, monitoring the position of vehicles in real time, logistic planning and assessment of the efficiency of transportation of goods and people (Kameneva et al., 2014; The World Economic Forum, 2018; Gruzinov et al., 2019).
The service part of the control system is supposed to be implemented in the form of electronic platform for placing applications for the transportation of goods and passengers from consumers. At the same time, the consumer, when ordering a service, sets its basic parameters, such as points of departure and destination, delivery time and transportation parameters, without worrying about the specifics of the route and the number of logistics operations. The executors of transport applications will be legal entities and individuals who are vehicle owners.

Development of innovative vehicles that do not require traditional transport infrastructure (small 


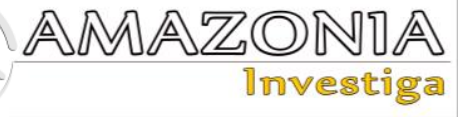

aircraft (Prosvirina, 2020), airships (Nsn.fm, 2017) and amphibious transport) of unmanned aircraft (Klochkov et al., 2020) and land transport and logistics systems, infrastructure elements for providing multimodal transportation will ensure the connectivity of sparsely populated and hardto-reach territories in the Arctic zone of the Russian Federation. It is not possible to solve this problem solely through the development of traditional communication routes and vehicles in the existing socio-economic situation. In addition, in the Arctic territories, the construction of roads and the arrangement of runways cause irreparable harm to ecosystems, as well as movement in such territories on heavy tracked vehicles.

In order to solve this problem as a part of integrated digital platform for interaction between carriers and customers, already used transport and logistics resources (Dudinskikh et al., 2018; Fatikhova et al., 2018) and vehicles that do not need traditional transport infrastructure will be combined.

The creation of a modular platform for the integrated development of territories and the development of existing settlements, allowing them to provide living conditions comparable to urban agglomerations, involves the creation of a set of technological solutions (buildings, structures, systems) for organizing autonomous life support in the following types of settlements:

- $\quad$ "Rotational Village": place of temporary residence of people engaged in the development of natural resources or solving technological problems in remote areas with severe climatic conditions;

- "Tourist Smart City": place of temporary stay of tourists, which provides the usual "urban" level of comfort, suitable for placement in the Arctic specially protected natural areas due to fully autonomous life support;

- $\quad$ "Arctic Smart City": place of permanent residence of people with different types of economic activity in harsh climatic conditions;

- "Smart Satellite City": place of permanent residence of people, which is tied to the "big city": it can be built as a modern microdistrict when solving the problem of resettlement of dilapidated and emergency housing stock and/or as a specialized satellite city (university campus, campus of modern medical center, etc.).

\section{Discussion}

The creation of a system of information and analytical support for making managerial decisions by public authorities and local selfgovernment bodies, including decisions on the choice of priorities for socio-economic development, optimization of the model of settlement and distribution of productive forces, optimal model of transport and logistics services and optimal model of energy supply, seems necessary to overcome the inconsistency and often the isolation of the main types of strategic and current planning: sectoral, regional, scientific and technological, as well as planning to ensure national security (Klepach and Razbegin, 2017; Klochkov, 2019).

The solution to this problem, allowing to synchronize and harmonize various approaches to forecasting and planning socio-economic development, can be a complex model of resource potential development and life support, which includes models of settlement, distribution of productive forces, transport and logistics services, energy supply, as well as socio-cultural model of the territory.

The result of the use of complex models should be an increase in the efficiency of the use of resources directed to the socio-economic development of the territories of the Arctic zone of the Russian Federation, increase in their investment attractiveness and optimization of the use of funds from state, sectoral and regional programmes (Roscongress, 2019; Veprikov et al., 2019).

The following approach define complex and scientific and technical tasks, ensure the consistency of goals and implementation mechanisms in strategic planning documents at various levels applied in an expert discussion on the draft Transport Strategy of the Russian Federation.

In February 2021, the Government of the Russian Federation is expected to consider the Transport Strategy of the Russian Federation until 2035.

The current version of it was approved by the Government of the Russian Federation in 2008 and revised in 2018 .

In 2020, the Ministry of Transport of the Russian Federation prepared and submitted for wide expert discussion a draft Transport Strategy until 2035, in which its goals, objectives, implementation mechanisms are determined 
taking into account the provisions of the Spatial Development Strategy of the Russian Federation, as well as national goals set in the Decree of the President of the Russian Federation dated July 21, 2020 № 474.

The draft of the updated Transport Strategy as a whole retains continuity to the current version of the document, but also includes a number of new provisions, including the use of the concept of "territorial connectivity", which, in turn, is based on the priority of the scientific and technological development of Russia, defined by paragraph 20e of the Strategy of Scientific-technological development of the Russian Federation.

If the current version of the Transport Strategy specifies "formation of a single transport space in Russia on the basis of a balanced advanced development of an efficient transport infrastructure" as the first strategic goal, then the draft of this document refers specifically to ensuring the connectivity of the territory of the Russian Federation, that is, a broader concept is used, not reducible solely to the development of communication lines and corresponding modes of transport.

The Council for the Priority of Scientific and Technological Development "Connectedness of the Territory of the Russian Federation" has prepared a number of proposals for the draft Transport Strategy of the Russian Federation until 2035, aimed at ensuring the connectivity of the territory in the Arctic zone of the Russian Federation.

The considered draft Transport Strategy of the Russian Federation for the period up to 2035 contains a forecast for eight key areas of development of sectors and spheres of public administration in the field of transport, namely:

- Road facilities;

- Railway transport;

- Sea transport and seaports;

- Water transport and inland waterways;

- Air transport and airport infrastructure, including regional and local air travel;

- Automobile transport;

- Urban passenger transport, off-street transport, transport systems of urban agglomerations;

- Arrangement of checkpoints across the state border.

Thus, the areas listed above cover traditional modes of transport and communication. But it seems necessary to take into account that ensuring the connectivity of such a geostrategic territory as Arctic cannot be achieved in the medium-term planning horizon solely through the development of traditional transport infrastructure. To ensure the connectivity of the territory of the Arctic zone of the Russian Federation, it is necessary to develop and implement innovative transport systems, to solve complex interdepartmental problems. In this regard, it is proposed to include in the Transport Strategy as an independent section a development forecast in the field of ensuring the connectivity of the territory of the Arctic zone of the Russian Federation.

In order to implement an interdepartmental approach, harmonize the Transport Strategy with strategic planning documents in the scientific and technological sphere, it is proposed to supplement the main mechanisms for the implementation of the Strategy with the item "Implementation of complex scientific and technical programs and projects of a full innovation cycle in the sphere of priority of scientific and technological development "Connectedness of the territory of the Russian Federation "...

The mechanism of formation and regular updating of scientific and technical problems, the solution of which is necessary for the successful implementation of the Transport Strategy, deserves attention, proposed by the Council for the priority direction of scientific and technological development "Connectedness of the territory of the Russian Federation".

It is proposed that the Council for the priority direction of scientific and technological development "Connectedness of the territory of the Russian Federation" be assigned to the Council for the priority direction of scientific and technological development "Connectedness of the territory of the Russian Federation" federal executive bodies that are responsible for the development of state policy and legal regulation in the development of transport systems, industry and regional development.

Determination and annual updating of the list of topical scientific and technical tasks in order to implement the Transport Strategy will contribute to increasing the efficiency of scientific and technical activities, including formation, selection and implementation of projects of the complete innovation cycle within SSTD.

This list of scientific and technical tasks will serve as a meaningful guide in the formation of 


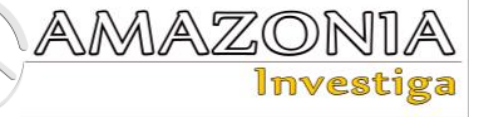

the topics of research and development work of scientific and educational centers, world-class scientific centers, state budget assignments of scientific and educational organizations specializing in priority areas of scientific and technological development defined in clauses 20a "Digital technologies, artificial intelligence, new materials", 20b "Environmentally friendly and resource-saving energy, new sources of energy", 20e "Connectedness of the territory of the Russian Federation" and 20g "Effective interaction of man, nature and technology" of SSTD.

In the considered draft of the Transport Strategy of the Russian Federation, in order to ensure the connectivity of sparsely populated and hard-toreach territories, it is proposed to include in the list of research and development work in areas that ensure the implementation of the Strategy, the development of innovative vehicles that do not need a traditional transport infrastructure (small aircraft, airships, amphibious transport), unmanned aircraft and ground transport and logistics systems, infrastructure elements to ensure the connectivity of sparsely populated and hard-to-reach areas.

\section{Conclusions}

A prerequisite for the implementation of SSTD, formation and implementation of complex scientific and technical programmes and projects of the full innovation cycle is the coordinated use of two approaches and their corresponding tools:

- $\quad$ administrative and political, based on the use of public funds to solve socially significant problems,

- market, based on the use of scientific and technical solutions in order to increase the competitiveness of products and business profitability.

The approaches proposed in this article to the definition of complex socio-economic problems and scientific and technical problems in their composition can be used as the basis for the formation of a comprehensive scientific and technical programme of a full innovation cycle, the result of which will increase the territorial connectivity and the quality of life in the geostrategic region: Arctic zone of the Russian Federation.

\section{References}

Bezrukov, L. A. (2015). Geographic Factors in the Development of Siberia: Discussion with
American Russianists. Economic Journal, 4(40), 109-130.

Dudinskikh, A. V., Kraev, V. M., and Tikhonov, A. I. (2018). Ensuring the connectivity of the territories of the Russian Federation with the help of air cargo transportation. Moscow Economic Journal, 4, 362-376.

Fatikhova, E. R., Kraev, V. M., and Tikhonov, A. I. (2018). Ensuring the connectivity of the territories of the Russian Federation through air passenger traffic. Moscow Economic Journal, 4, 411-419.

Grebennikov, V. V., Munin, D. A., Levashev, A. G., and Mikhailov, A.Yu. (2012). Types of transport accessibility. Proceedings of universities. Investments. Building. Real estate, 1(2), 56-61.

Gruzinov, V. M., Zvorykina, Yu. V., Ivanov, G. V., Sychev, Yu. F., Tarasova, O. V., and Filin, B. N. (2019). Arctic transport routes on land, water areas and airspace. Arctic: Ecology and Economics, 1(33), 6-20.

Hill, F., and Gaddy, C. (2003). The Siberian Curse. How Communist Planners Left Russia Out in the Cold. Washington: The Brookings Institution.

Kameneva, N. A. (2014). The main directions of economic development of the transport infrastructure of Russia. universe: Economics and Law, 3(4).

Klepach, A. N., and Razbegin, V. N. (2017). The role of transport projects in the development of the Arctic and the Russian North. State audit. Law. Economy, 1, 121-124.

Klochkov, V. V. (2019). Interrelation of strategies of scientific, technological and spatial development of Russia. Academy of Knowledge Bulletin, 14(1), 101-106.

Klochkov, V. V., Karpov, A. E., and Tikhonov, A. I. (2020). The effectiveness of the use of unmanned aerial vehicles to ensure the connectivity of the territories of the Russian Federation. Academy of Knowledge Bulletin, 2(37), 144-149.

Mikhailova, T. N. (2011). Geography is not destiny! (Commentary on "The Siberian Curse" by F. Hill and C. Gaddy). Journal of Institutional Studies, 3(1), 97-103.

Novikov, S., Komarova, N., \& Dadyan, K. (2019). Development of a motivation system and supporting the success of the internal and external interactions of the network project group. Amazonia Investiga, 8(20), 200-209. Retrieved from https://amazoniainvestiga.info/index.php/amazo nia/article/view/79

Nsn.fm (2017). Press conference "Airship Building in Russia: Utopia or Innovation?" 
Available online: http://nsn.fm/presscenter/dirizhablestroenie-v-rossii-utopiya-ilinovaciya.html (accessed on 02 August 2021).

Pogosyan, M. A., Strelets, D. Yu., and Vladimirova, V. G. (2019). Connectedness of the territory of the Russian Federation: from the formulation of complex tasks to the formation of complex scientific and technical projects. Bulletin of the Russian Academy of Sciences, 89(5), 489-495.

Prosvirina, N. V. (2020). Analysis of the problems of small aircraft in Russia and possible ways to solve them. Natural and humanitarian research, 2(28), 232-238.

Roscongress (2019). Proceedings of the session "Comprehensive scientific and technical programs and projects for the development of the Arctic: dialogue of potential partners" of the V International Arctic Forum "The Arctic Territory of Dialogue" (April 2019). Available online: https://roscongress.org/sessions/iaf2019-kompleksnye-nauchno-tekhnicheskieprogrammy-i-proekty-dlya-osvoeniya-arktikidialog-potentsialnykh-p/discussion/ (accessed on 02 August 2020).

Shelomentsev, A. G., Smirennikova, E. V., Ukhanova, A. V., and Voronina, L. V. (2018). Analysis of migration processes in the regions of the Arctic zone of the Russian Federation.
Academy of Scientific Research: Economics and Management, 4(25), 347-350.

Shepelev, G. V. (2020). On the management of Russian science. Science management: theory and practice, 2(2), 65-92.

The World Economic Forum (2018). The Global Competitiveness Report 2017-2018. Available online:

http://www3.weforum.org/docs/GCR2017-

2018/05FullReport/TheGlobalCompetitiveness Report2017\%E2\%80\%932018.pdf (accessed on 02 August 2021).

Veprikov, E. B., Kislenok, A. A., Lee, E. L., Novitsky, A. A., and Pokrashenko, P. A. (2019). Proposals for the draft National Program for the Development of the Far East ("social" section). Khabarovsk: Eastern Center for State Planning.

Voronina, L. V., Smirennikova, E. V., and Ukhanova, A. V. (2018). Features of migration processes in the Arctic region. In Proceedings of the Actual problems, directions and mechanisms of development of the productive forces of the North-2018, Syktyvkar, Russia, 233-237.

Дв2025.pф. (2018). Proposals submitted to the National Program for the Development of the Far East until 2025. Available online: https://дв2025.pф/suggests (accessed on 02 August 2021). 